\title{
INFLUENCE OF THE SPECIFIC LOAD ON THE KINETICS OF THE PROCESS OF CONVECTIVE-THERMO- RADIATION DRYING OF APPLE SNACKS
}

\author{
L. Strelchenko, I. Dubkovetsky, I. Malezhyk \\ National University of Food Technologies
}

\begin{tabular}{l}
$\quad$ Key words: \\
Technology \\
Blanching \\
Drying \\
Moisture content \\
Vitamin C \\
Energy consumption \\
Snack \\
\hline
\end{tabular}

Article history:

Received 14.05.2018

Received in revised form 05.06.2018

Accepted 15.06.2018

Corresponding author:

L. Strelchenko

E-mail:

lanovenkol@i.ua

\begin{abstract}
Snacks are one of the varieties of the so-called "fast food" that is common in the modern world. There is a large number of snacks, both natural and with various additives. Based on the market analysis of snacks in Ukraine, there was a necessity to develop a new product that can be eaten by people with certain limitations and even children. The effectiveness of the drying process essentially depends on the specific loading of the raw material, which is determined by the mass $(\mathrm{kg})$, referenced to unit area $\left(\mathrm{m}^{2}\right)$. The development of a new apple snack technology allows to get a product with low calorie content and a balanced chemical composition. In order to determine the optimal specific load of the semi-finished product, the study was carried out at a laboratory installation at different loads: $2.2 \mathrm{~kg} / \mathrm{m}^{2}, 4.4 \mathrm{~kg} / \mathrm{m}^{2}, 6.6 \mathrm{~kg} / \mathrm{m} 2,8.8 \mathrm{~kg} / \mathrm{m}^{2}$ and $11.0 \mathrm{~kg} / \mathrm{m}^{2}$. As a result of research, five samples of snakes were obtained.

The organoleptic and physical-chemical analysis of the obtained snacks showed that the optimal specific load on the dryer is $8.8 \mathrm{~kg} / \mathrm{m}^{2}$. The raw material for drying was the fall grade "Golden Delishes" apples. A particular advantage of these apples is the large fruit value (greater than $200 \mathrm{~g}$ ), a greater ratio than other types of pulp to the seed chamber and a smaller peel thickness. This allows to minimize waste, which is essential, especially on an industrial scale. This variety of apples has high initial values, including the content of sugars and the sugar-acid index. The rational parameters of drying and intensification of the process are achieved by a combination of such drying parameters as shape and size of the material and its specific load. The combination of convective and thermo-radiation drying with impulse heat transfer to the apple snake surface allowed to achieve the desired qualitative technological characteristics and reduce energy costs compared to convective or thermos-radiation drying. The mechanism and intensity of the transfer of moisture in the material depend on the form of connection of moisture with the material, the diffusion of the vapor-gas medium through the capillary-pore structure of the material. The work presents the curves of drying and drying rates, the dependence of the heat and mass transfer coefficients under different loads by convective thermo-radiation power supply.
\end{abstract}

DOI: $10.24263 / 2225-2924-2018-24-3-16$ 


\title{
ВПЛИВ ПИТОМОГО НАВАНТАЖЕННЯ НА КІНЕТИКУ ПРОЦЕСУ ПРИ КОНВЕКТИВНО-ТЕРМОРАДІАЦІЙНОМУ СУШІННІ ЯБЛУЧНИХ СНЕКІВ
}

\author{
Л.В. Стрельченко, І.В. Дубковецький, І.Ф. Малежик \\ Національний університет харчових технологій
}

Снеки є одним з різновидів розповсюдженої в сучасному світі так званої «швидкої їжі». Існуе велика кількість як натуральних снеків, так $і$ з різними добавками. На основі аналізу ринку снеків в Україні виникла потреба в розробиі нового продукту, яким можуть харчуватися люди з певними обмеженнями $i$ навіть діти. Розробка нової технологї̈ яблучних снеків дає змогу отримати продукт з невисокою калорійністю та збалансованим хімічним складом.

3 метою встановлення оптимального питомого навантаження напівфабрикату дослідження виконували на лабораторній установиі при різних наван-

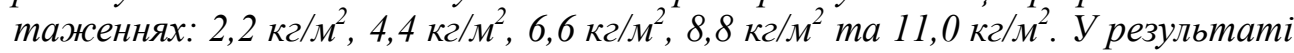
досліджень отримали п'ять зразків снеків. Органолептичний і фізико-хімічний аналіз одержаних снеків показав, що оптимальним питомим навантаженням на сушарку є $8,8 \kappa 2 / \mathrm{m}^{2}$.

Сировиною для сушіння був осінній сорт яблук Голден Делішес. Особливою перевагою цих яблук є значна величина плоду (більше 200 г), більше співвідношення порівняно з іншими сортами м'якоті до насіннєвої камери і менша товщина шкірки. Це дає змогу мінімізувати відходи, щяо має суттєве значення, особливо в промислових масштабах. Цей сорт яблук відрізняється високими вихідними показниками, зокрема вмістом иукрів і иукрово-кислотним індексом. Раиіональні параметри сушіння та інтенсифікація процесу досягається комбіначією таких параметрів сушіння, як форма та розміри матеріалу $i$ його питоме навантаження. Комбіначія конвективного $і$ терморадіаційного сушіння при імпульсному донесенні теплоти до поверхні яблучних снеків забезпечила бажані якісні технологічні характеристики і зменшення витрат енергї порівняно з конвективним чи терморадіаційним сушінням. 3'ясовано, що механізм та інтенсивність перенесення вологи у матеріалі залежать від форми зв'язку вологи з матеріалом, дифузї парогазового середовища через капілярно-порову структуру матеріалу. Наведено криві сушіння і швидкості сушіння, залежності коефічіснтів тепломасообміну при різних навантаженнях конвективно-терморадіаџійним енергопідведенням.

Ключові слова: технологія, бланшування, сушіння, вологовміст, вітамін С, витрати енергії, снек.

Постановка проблеми. Сучасний ринок снеків в Україні представлений як вітчизняними, так і закордонними виробниками. Снеки закордонного виробництва дорожчі, тому попит на них в останні роки дещо знизився, бо споживач надає перевагу в основному вітчизняним снекам. Основною відмінністю снека $\epsilon$ розмір шматочків і зручність вживання через відсутність попередньої підготовки. Серед вітчизняних снеків споживач надає перевагу сухофруктам. 
Якщо аналізувати сегмент сухофруктів, то передусім він представлений яблуками. Проте якість таких продуктів бажала б бути кращою, а асортимент різноманітнішим. У зв'язку з цим постає завдання розробки нових інноваційних харчових продуктів із невисокою калорійністю та високою харчовою цінністю.

Аналіз останніх досліджень і публікацій. За останні роки були запропоновані нові технології з виробництва яблучних снеків із застосуванням конвективного [3], мікрохвильового [4], сублімаційного [5] та вакуумного сушіння [6], але вони мають суттєвий недолік - енергоємність. Запропонований нами конвективно-терморадіаційний спосіб сушіння [7] знижує енерговитрати до $30 \%$ порівняно 3 конвективним.

Мета статті: розроблення технології яблучних снеків з високими органолептичними показниками, збалансованим хімічним складом і значною харчовою цінністю.

Викладення основних результатів дослідження. Попередньо підготовлені яблука бланшували протягом 90 секунд в 30-відсотковому цукровому сиропі $з$ додаванням органічної (лимонної) кислоти та антиоксиданту. Сушіння виконували інфрачервоними промінням в імпульсному режимі нагрів-охолодження 3 довжиною хвилі в діапазоні $1,2 \ldots 4$ мкм та щільністю теплового потоку $5,5 \mathrm{\kappa BT} / \mathrm{m}^{2}$. Температура сушіння яблучних снеків становила $60^{\circ} \mathrm{C} .3$ метою інтенсифікації процесу сушіння одночасно з інфрачервоним здійснювалось конвективне сушіння 3 рециркуляцією повітря 50/50\% [10; 11]. Для встановлення оптимального питомого навантаження сушарки було дослідже-

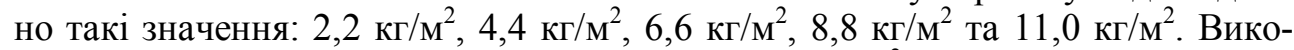
ристання питомого навантаження менше ніж 2,2 кг/м² призводить до нераціонального використання ресурсів сушарки, тому що вона працює не на повну потужність. А використання питомого навантаження більше 11,0 кг $/ \mathrm{m}^{2}$ призводить до перевантаження установки, що теж нераціонально.

На основі отриманих даних були побудовані криві сушіння (рис. 1), що характеризують зміну вологовмісту $W^{c}$ залежно від часу $\tau$. Звідси видно, що період прогріву для всіх зразків мінімальний, а швидкість видалення вологи відбувається прямо пропорційно збільшенню питомого навантаження.

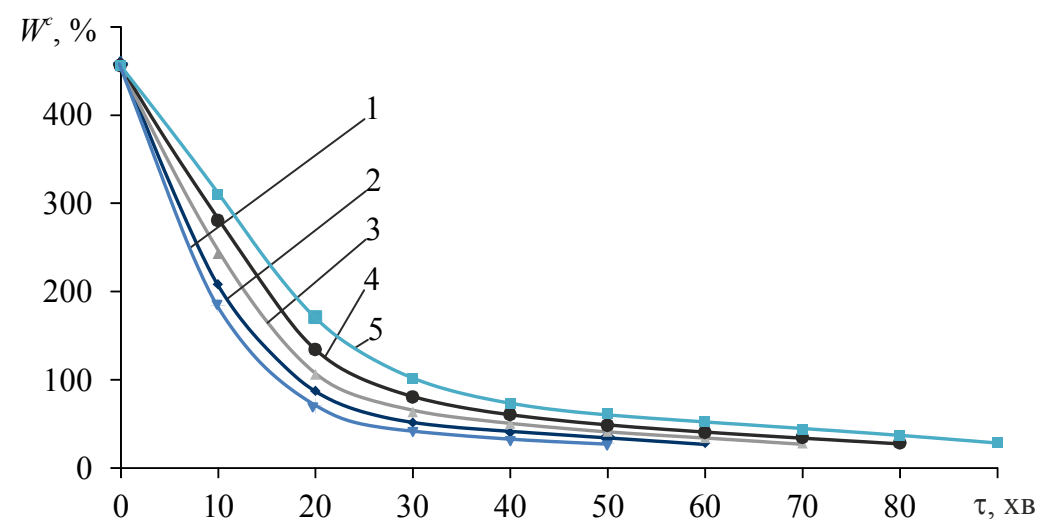

Рис. 1. Криві сушіння бланшованих яблук при різному питомому навантаженні: $1-2,2 \mathrm{\kappa} / \mathrm{M}^{2} ; 2-4,4 \kappa \Gamma / \mathrm{M}^{2} ; 3-6,6 \mathrm{\kappa} / \mathrm{M}^{2} ; 4-8,8 \mathrm{\kappa} / \mathrm{M}^{2} ; 5-11 \mathrm{\kappa} / \mathrm{M}^{2}$ 
Апроксимуючи дані першого та другого періодів сушіння (рис. 1), вивели рівняння залежності вологовмісту $W^{c}$ від часу сушіння $\tau$ і питомого наванта-

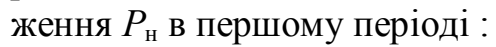

$$
W^{c}=\left(0,0702 P_{\mathrm{H}}-31,309\right) \tau-0,0622 P_{\text {н }}+462,68 \text { при } R^{2}=0,98 ;
$$

у другому періоді:

$$
W^{c}=\left(-0,075 P_{\mathrm{H}}-92,634\right) \ln (\tau)+248,4 P_{\mathrm{H}}{ }^{0,113} \text { при } R^{2}=0,95,
$$

де $W^{c}$ - вологовміст, \%; $\tau$ - час, хв; $P_{\text {н }}$ - насипна маса продукту, кг $/ \mathrm{m}^{2} ; R^{2}-$ коефіцієнт кореляції.

У результаті обробки кривих сушіння отримані залежності швидкості сушіння бланшованих яблук від вологовмісту (рис. 2), що дають змогу проаналізувати динаміку сушіння зразків. При виведенні рівняння кінетики сушіння 3 експериментальних залежностей $d W^{c} / d \tau$ від $W^{c}$ встановили, що в перший період швидкість сушіння для кожного навантаження $є$ постійною, але зменшується при збільшенні питомого навантаження. А починаючи з 2-го періоду сушіння вплив питомого навантаження на швидкість сушіння зменшується при зменшенні вологовмісту матеріалу.

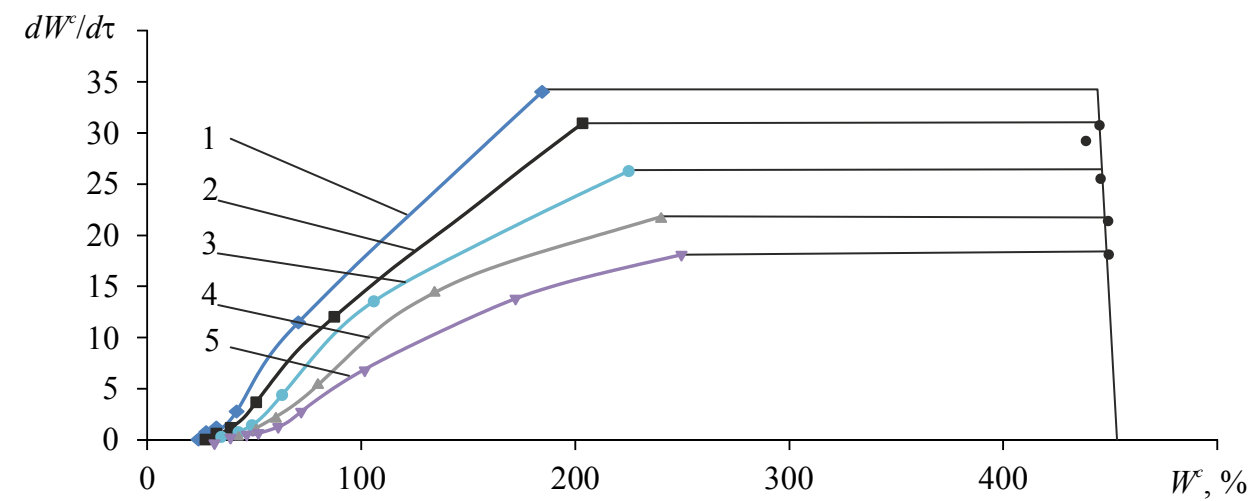

Рис. 2. Криві швидкості сушіння бланшованих яблук при питомому навантаженні: $1-2,2 \kappa \Gamma / \mathrm{M}^{2} ; 2-4,4 \kappa \Gamma / \mathrm{M}^{2} ; 3-6,6 \kappa \Gamma / \mathrm{M}^{2} ; 4-8,8 \mathrm{\kappa} \Gamma / \mathrm{M}^{2} ; 5-11 \mathrm{\kappa} / \mathrm{M}^{2}$

Проаналізувавши другий період сушіння, вивели для всіх зразків апроксимаційне рівняння залежності швидкості сушіння $\tau$ від вологовмісту $W^{c}$ продукту і питомого навантаження $P_{\mathrm{H}}$ :

$$
d W^{c} / d \tau=\left(21,93 \mathrm{e}^{-0,004 P_{\mathrm{H}}}\right) W^{c}+0,149 P_{\mathrm{H}}-67,94 \text { при } R^{2}=0,97,
$$

де $W^{c}-$ вологовміст,\%; $\tau-$ час, хв; $P_{\text {н }}$ - питоме навантаження; $R^{2}-$ коефіцієнт кореляції.

На основі обробки графічних залежностей кривих сушіння і швидкості сушіння визначили залежності коефіцієнтів швидкості сушіння в першому і в другому періодах, а також тривалість прогріву напівфабрикату, тривалість першого та другого періодів. Результати наведені в табл. 1 та на рис. 3. За коефіцієнтами швидкості сушіння в другому періоді вивели апроксимаційне рівняння (рис. 3). 
Таблиця 1. Коефіцієнти швидкості сушіння снеків залежно від питомого навантаження

\begin{tabular}{|c|c|c|c|c|c|c|c|c|c|}
\hline № & $P_{\text {н }}$, Кг $/ \mathrm{M}^{2}$ & $W_{\text {кр }}^{c} \%$ & $d W^{c} / d \tau, \% / \mathrm{xв}$ & $\mathrm{K}_{1}, \% / \mathrm{c}^{-1}$ & $\mathrm{~K}_{2}, \% / \mathrm{c}^{-1}$ & $\tau_{\text {пр }}, \mathrm{Xв}$ & $\tau_{1}, \mathrm{Xв}$ & $\tau_{2}, \mathrm{Xв}$ & $\tau_{\text {заг }}$, Хв \\
\hline 1 & 2,2 & 184 & 34,22 & 0,125 & 1,38 & 2 & 10 & 40 & 50 \\
\hline 2 & 4,4 & 208 & 31,15 & 0,125 & 0,503 & 2 & 15 & 45 & 60 \\
\hline 3 & 6,6 & 243 & 26,5 & 0,125 & 0,44 & 2 & 20 & 50 & 70 \\
\hline 4 & 8,8 & 280 & 21,94 & 0,125 & 0,24 & 2 & 20 & 60 & 80 \\
\hline 5 & 11,0 & 310 & 18,19 & 0,125 & 0,202 & 2 & 20 & 70 & 90 \\
\hline
\end{tabular}

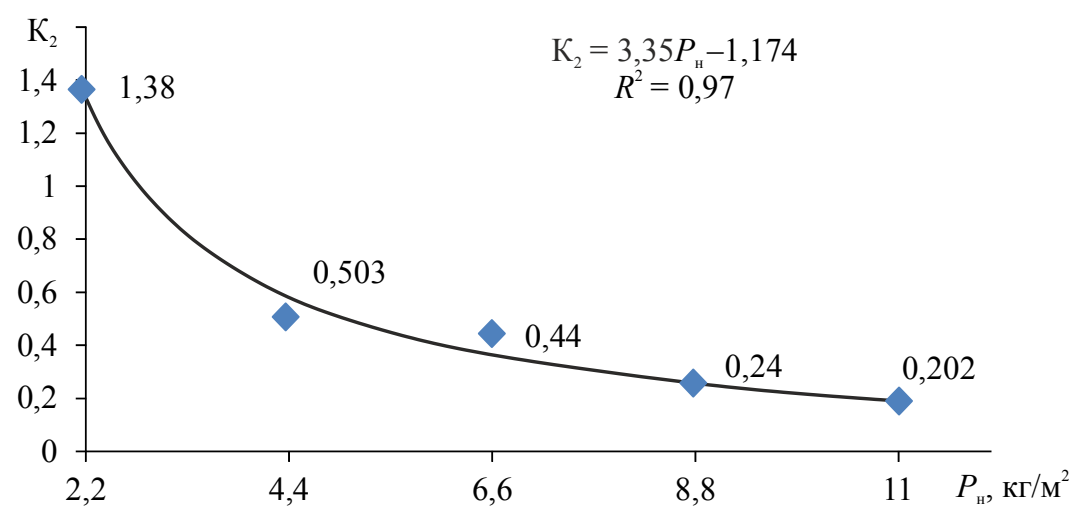

Рис. 3. Коефіціснти швидкості сушіння для снеків у другому періоді сушіння при різному питомому навантаженні

Після сушіння отримали п’ять зразків снеків з яблук Голден, для об'єктивної оцінки яких був проведений якісний аналіз. Органолептичні показники зразків практично не відрізнялися, окрім зразка з питомим навантаженням 11 кг/м², який відрізнявся невираженим запахом і темним локальним кремовим кольором. Темний колір пояснюється окисненням поверхні продукту киснем повітря внаслідок тривалого видалення вологи. Фізико-хімічні показники готових продуктів представлені в табл. 1. Вміст сухих речовин у свіжих яблук становить $14,2 \%$.

Фізико-хімічний аналіз показав (табл. 2), що найменший вміст вітаміну С виявився в зразку з питомим навантаженням $11,0 \mathrm{\kappa г} / \mathrm{m}^{2}-6,8 \mathrm{мг} \%$ в продукті. В інших зразках вміст вітаміну С практично не відрізнявся. Саме тому, 3 огляду на якісний аналіз зразків, можна вважати, що оптимальним питомим навантаженням є 8,8 кг/м² продукту. Адже при меншому питомому навантаженні відбувається нераціональне використання ресурсів сушарки при тій же якості готового продукту.

Табличя 2. Фізико-хімічний аналіз снеків, отриманих при різному питомому навантаженні

\begin{tabular}{|c|c|c|c|c|c|}
\hline \multirow{2}{*}{ Найменування показника } & \multicolumn{5}{|c|}{ Снеки, отримані при питомому навантаженні } \\
\cline { 2 - 6 } & 2,2 & 4,4 & 6,6 & 8,8 & 11,0 \\
\hline 1 & 2 & 3 & 4 & 5 & 6 \\
\hline Сухі речовини яблук, \% & 87,5 & 87,5 & 87,5 & 87,5 & 87,5 \\
\hline Моно- та дицукри, \% & 64,2 & 64,2 & 64,2 & 64,2 & 64,2 \\
\hline
\end{tabular}




\begin{tabular}{|c|c|c|c|c|c|}
\hline \multicolumn{5}{c|}{ Продовження табл. 2 } \\
\hline 1 & 2 & 3 & 4 & 5 & 6 \\
\hline Органічні кислоти , \% & 2,1 & 2,2 & 2,2 & 2,1 & 1,6 \\
\hline Пектинові речовини, \% & 2,1 & 2,3 & 2,6 & 2,8 & 5,8 \\
\hline Клітковина, \% & 1,8 & 1,9 & 2,1 & 2,45 & 5,3 \\
\hline Мінеральні речовини, \% & 7,9 & 8,0 & 7,8 & 5,6 & 3,5 \\
\hline Вітамін С, мг \% & 8,6 & 8,63 & 8,5 & 8,54 & 6,8 \\
\hline
\end{tabular}

При обробці даних процесу сушіння одержано витрати енергії для всіх зразків снеків в кВт · год на кг вихідної сировини (рис. 4а) і в МДж/кг випареної вологи (рис. 4б).

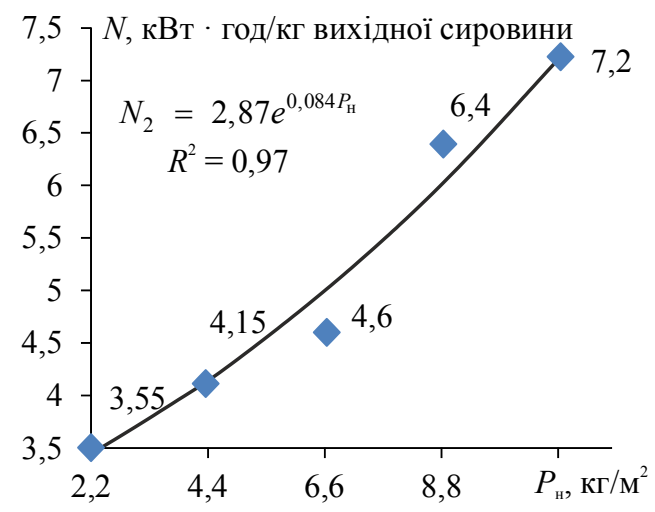

a

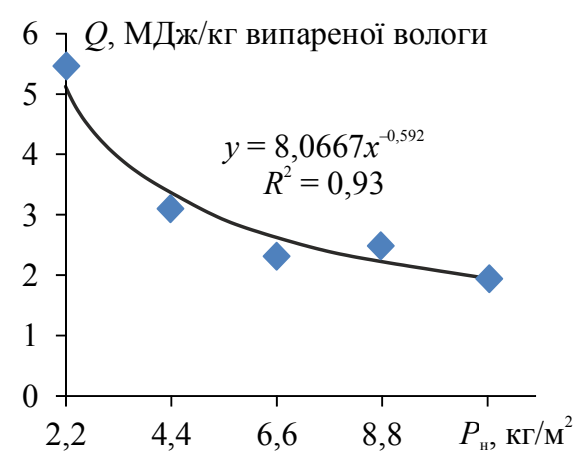

6

Рис. 4. Витрата електроенергії на 1 кг вихідної сировини (4a) і на 1 кг випареної вологи (4б) при різному питомому навантаженні

3 рис. 4 видно, що найвищі витрати енергії склали для снеків, що суши-

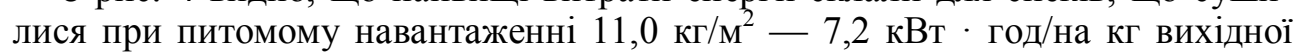
сировини, а найнижчі 3,55 кВт · год/на кг вихідної сировини для снеків, що

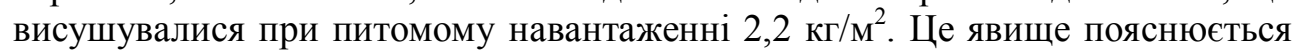
тим, що із збільшенням питомого навантаження збільшується час сушіння.

У зв'язку з істотним впливом питомого навантаження на різні параметри процесу сушіння доцільним є встановлення оптимальних його значень.

Кількість теплоти, що витрачається на випаровування вологи при температурі $60^{\circ} \mathrm{C}$ при різному питомому навантаженні представлено в табл. 3 .

Таблиця 3. Кількість теплоти, що витрачається при різному питомому навантаженні (температура повітря $60^{\circ} \mathrm{C}$ )

\begin{tabular}{|c|c|c|c|c|}
\hline \multirow{2}{*}{$\begin{array}{c}\text { Питоме навантаження } \\
P_{\text {н }}, \text { кг/м }\end{array}$} & \multirow{2}{*}{$\begin{array}{c}\text { Тривалість } \\
\text { сушіння } \tau, \text { хв }\end{array}$} & $\begin{array}{c}\text { кВт год/кг } \\
\text { вологи }\end{array}$ & МДж/кг вологи & $\begin{array}{c}\text { кВт } \cdot \text { год/кг } \\
\text { вихідної } \\
\text { сировини }\end{array}$ \\
\hline 2,2 & 50 & 182 & 5,42 & 3,55 \\
\hline 4,4 & 60 & 370 & 3,12 & 4,15 \\
\hline 6,6 & 70 & 554 & 2,3 & 4,6 \\
\hline 8,8 & 80 & 709,5 & 2,5 & 6,4 \\
\hline 11,0 & 90 & 1002,5 & 1,9 & 7,2 \\
\hline
\end{tabular}


Площа зовнішньої поверхні кілограма висушеного продукту при умові, що сировина нарізається на частинки у формі паралелепіпеда 3 розмірами $30 \times 3 \times 15$ мм становить:

$$
F=2 \cdot(a \cdot b+a \cdot h+b \cdot h) \cdot n, \mathrm{~m}^{2} / \text { кг вихідної сировини, }
$$

де $a, b, h-$ відповідно, довжина, ширина і висота частинки снека, м; $n-$ кількість частинок на м².

Коефіцієнт теплообміну розраховуємо за формулою:

$$
\alpha=Q /\left(\Delta t_{\mathrm{cp}} \cdot F\right),
$$

де $\Delta t_{\mathrm{cp}}=t_{\text {п }}-t_{\mathrm{cp}} ; t_{\text {п }}$ - температура матеріалу ( в першому періоді сушіння рівна температурі мокрого термометра); $t_{\text {п }}$ - середньоарифметична температура повітря в сушильній камері. Результати розрахунків наведені в табл. 4.

Таблиця 4. Площа зовнішньої поверхні кілограма висушеного продукту та коефіцієнт теплообміну при різному питомому навантаженні (температура повітря

\begin{tabular}{|c|c|c|}
\hline $\begin{array}{c}\text { Питоме навантаження } P_{\mathrm{H}} \text {, } \\
\kappa \Gamma / \mathrm{m}^{2}\end{array}$ & $\begin{array}{c}\text { Площа зовнішньої поверхня } \\
\text { кіло-грама висуше-ного } \\
\text { продукту } F, \text { м }^{2} \text { кг вихідної } \\
\text { сировини }\end{array}$ & $\begin{array}{c}\text { Коефіцієнт теплообміну } \alpha \\
\text { при сушінні }\end{array}$ \\
\hline 2,2 & 0,702 & 561,89 \\
\hline 4,4 & 1,404 & 328,43 \\
\hline 6,6 & 1,989 & 256,97 \\
\hline 8,8 & 2,633 & 249,85 \\
\hline 11,0 & 3,276 & 244,20 \\
\hline
\end{tabular}
$60^{\circ} \mathrm{C}$ і швидкість руху повітря в камері $5,5 \mathrm{~m} / \mathrm{c}$ )

У процесі обробки дослідних даних одержали графік залежності коефіцієнта теплообміну від питомого навантаження та відповідне апроксимаційне рівняння (рис. 5).

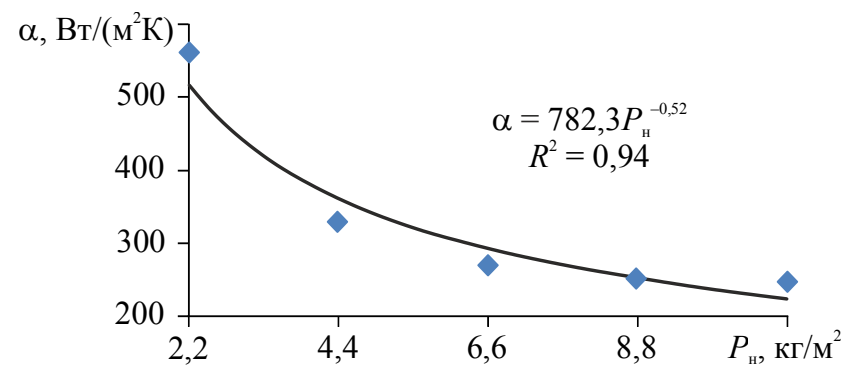

Рис. 5. Залежність коефіціснта тепловіддачі при сушінні яблучних снеків від питомого навантаження

При дослідженні періодів сушіння швидкість процесу сушіння визначали за станом навколишнього середовища й умовами сушіння, а повний потік вологи виражався через об'ємний коефіцієнт масовіддачі:

$$
J=d W^{c} / d \tau=\beta\left(x_{\Gamma}-x\right)=\beta\left(x_{1}-x\right),
$$

де $x_{\text {г }}$ - вологовміст повітря (кг/кг) на межі частинки, який вважається рівноважним; $x_{\mathrm{r}}=x_{1}$ - вологовміст повітря при постійній швидкості (перший 
період) сушіння (кг/кг), який знаходили за психрометричними даними. Молярна маса води $M_{\text {в }}=18$, повітря $M_{\text {п }}=29$, відносна вологість повітря $\varphi=64 \%$. Парціальний тиск насиченої водяної пари $P$ при температурі t знаходили 3 таблиць, а мольні долі $\mathrm{m}$ - зі співвідношення $m_{1}=P t_{1} /\left(1-P t_{1}\right), P t_{1}=P t / 760$. При температурі $21^{\circ} \mathrm{C} P t_{21}=18,66 / 760=0,025$. Молярна частка при $21^{\circ} \mathrm{C} m_{2}=$ $=P t_{21} \varphi /\left(1-P t_{21}\right)=0,016$. Вологовміст повітря в першому періоді знаходиться за формулою:

$$
x_{1}=\left(M_{\mathrm{B}} / M_{\mathrm{\Pi}}\right)\left(m_{1} /\left(1-m_{1}\right)\right) .
$$

Вологовміст:

$$
x=\left(M_{\mathrm{B}} / M_{\text {пा }}\right)\left(m_{2} /\left(1-m_{2}\right)\right)=0,01 .
$$

Результати розрахунку наведені в табл. 5.

Таблиця 5. Фізичні показники залежно від температури теплоносія

\begin{tabular}{|c|c|c|c|c|}
\hline $\begin{array}{c}\text { Температура } \\
\text { теплоносія t, }{ }^{\circ} \mathrm{C}\end{array}$ & $\begin{array}{c}\text { Парціальний тиск } p t, \\
\text { мм рт. ст }\end{array}$ & $\begin{array}{c}\text { Парціальний } \\
\text { тиск } p t_{21}, \\
\text { мм рт. ст }\end{array}$ & $\begin{array}{c}\text { Молярна } \\
\text { частка, } m_{l}\end{array}$ & $\begin{array}{c}\text { Вологовміст } \mathrm{x}_{1}, \\
\text { кг/кг }\end{array}$ \\
\hline 60 & 26 & 0,034 & 0,035 & 0,023 \\
\hline
\end{tabular}

Результати визначення потоку вологи $J=d W / d \tau$ і коефіцієнта масовіддачі $\beta=J /\left(x_{1}-x\right)$ при різному питомому навантаженні наведені в табл. 6.

Таблиия 6. Потік вологи при сушінні та коефіціснт масовіддачі залежно від питомого навантаження (температура повітря $60^{\circ} \mathrm{C}$ і швидкість руху повітря в камері $5,5 \mathrm{M} / \mathrm{c})$

\begin{tabular}{|c|c|c|}
\hline Питоме навантаження $P_{\mu}$, кг/м & Потік вологи при сушінні & Коефіцієнт масовіддачі $\beta, \mathrm{m} / \mathrm{c}$ \\
\hline 2,2 & 34,22 & 2632,31 \\
\hline 4,4 & 31,15 & 2396,15 \\
\hline 6,6 & 26,5 & 2038,46 \\
\hline 8,8 & 21,94 & 1687,69 \\
\hline 11,0 & 18,19 & 1399,23 \\
\hline
\end{tabular}

У результаті обробки експерименту отримано залежність коефіцієнта масовіддачі від питомого навантаження $\beta=f\left(P_{\mathrm{H}}\right)$ (рис. 6).

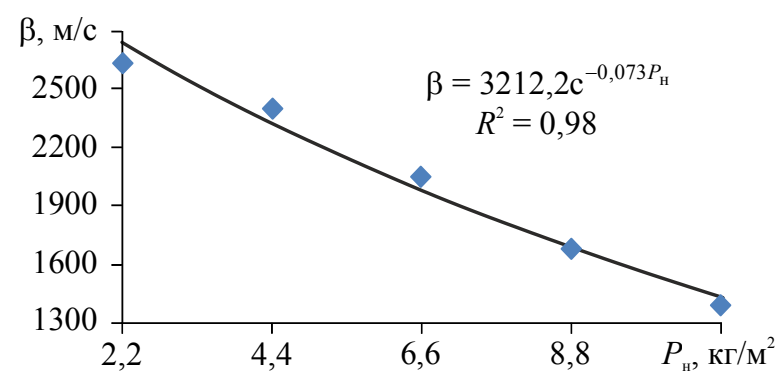

Рис. 6. Залежність коефіціснта масовіддачі від питомого навантаження

3 рис. 6 видно, що чим більше питоме навантаження напівфабрикату в сушарці, тим менший коефіцієнт масовіддачі. 


\section{Висновки}

Зважаючи на якісний аналіз одержаних яблучних снеків, можна зробити висновок, що оптимальним питомим навантаженням $\epsilon 8,8$ кг/м ${ }^{2}$ яблучного напівфабрикату, при якому харчова цінність і вітамінний комплекс продукту зберігаються повною мірою. Продукт, створений без додавання консервантів, ароматизаторів і підсилювачів смаку, можна рекомендувати практично всім групам населення, окрім тих, в кого $є$ обмеження за вживанням цукрози.

У перспективі планується дослідження процесу конвективно-терморадіаційного сушіння яблучних снеків у промислових установках.

\section{Література}

1. Malejik I. Investigation of drying apple snack convection-termoradiatsiynym energy to wrap different power heaters // Proceeding of International Conference "Modern Technologies in the food Industry" / I. Malejik, I. Strelchenko, I. Dubkovetsky - Chisinau, 2016, pages. $64-68$.

2. Malejik I. The Use of convective-thermoradiactive method of energy supply in the apple snack technology // Східно-Свропейський журнал передових технологій / I. Malejik, I. Dubkovetsky, H. Bandurenko, L. Strelchenko, T. Levkivska — 2016, 6/11(84), pages.47-52.

3. Velickova E. Physical and sensory properties of ready to eat apple chips produced by osmo-convective drying [Text] / Journal of Food Science and Technology / E. Velickova, E. Winkelhausen, S. Kuzmanova - December 2014, Volume 51, Issue 12, pages 3691-3701.

4. Noorbakhsh R. Radiant energy under vacuum (REV) technology: A novel approach for producing probiotic enriched apple snacks [Text] / Journal of Functional Foods, July / R. Noorbakhsh, Y. Parastoo, T. Durance - 2013, volume 5, issue 3, pages 1049-1056.

5. Hawkes J. Osmotic concentration of fruit slices prior to freeze dehydration [Text] / Journal of Food Processing and Preservation / J. Hawkes, J. Flink — 2015, vol. 19782(4): page 265.

6. Jinfeng Bi. Effects of pretreatments on explosion puffing drying kinetics of apple chips [Text] / Food Science and Technology / Bi. Jinfeng, Y. Aijin, L. Xuan, W. Xinye, C. Qinqin, EW. Qiang, Lv. Jian, X. Wang - march 2015, volume 60, issue 2, part 2, pages 1136-1142.

7. Радіаційно-конвективна сушильна установка. Патент на винахід України № 112348 МПК F26B 3/30, F26B 3/04, F26B 9/06, F26B 21/04, F26B 21/08, F26B 21/10, F26B 21/12, A23В 7/02 [Текст] / Дубковецький І.В., Малежик І.Ф., Бурлака Т.В., Стрельченко Л.В. - a 201411435 ; заявл. 20.10 .2014 ; опубл. 25.08.16, Бюл. № 16. -5 c.

8. Спосіб виробництва яблучних снеків. Патент на винахід України № 113587 МПК A23L 19/8, A23В 7/02 [Текст] / Малежик I.Ф., Дубковецький І.В., Бандуренко Г.М., Стрельченко Л.В. — а 201511035; заявл. 11.11.2015; опубл. 10.02.17, Бюл. № $3 .-5$ с

9. Спосіб виробництва яблучних снеків. Патент на корисну модель України № 105128 МПК A23L 3/46, A23B 7/026 [Текст] / Малежик I.Ф., Дубковецький I.В., Бандуренко Г.М., Стрельченко Л. В. — а 201507404; заявл. 23.07.2015; опубл. 10.03.16, Бюл. № 5. — 3 с

10. Гинзбург А.С. Инфракрасная техника в пищевой промышленности [Текст] / А.С. Гинзбург, В.В. Гортинский, А.Б. Демский, М.А. Борискин. - Москва : пищевая промышленность, 1966. - С. 407.

11. Стррельников А.В. Инновационные подходы к переработке плодово-ягодной продукции $[$ Текст] / Технологии пищевой и перерабатывающей промышленности АПК продукты здорового питания // А.В. Стрельников. — 2015. — Выпуск 1(5). — С. 95-101. 